\title{
KIDS, GUNS, AND HOMICIDE: POLICY NOTES ON AN AGE-SPECIFIC EPIDEMIC
}

\author{
FRANKLIN E. ZIMRING*
}

\section{INTRODUCTION}

Concern about the violent young offender is a cyclical phenomenon in the United States, usually lagging a few years behind general public alarm about rising crime rates. The sharp increase in violent crime in the United States between 1965 and 1974 occurred without any particular focus on adolescent offenders. After 1975 and until the beginning of the 1980s, however, youth crime and the young offender became the featured problem in public and legislative debates. ${ }^{1}$ The moral panic about drugs and drug control that was launched in the mid-1980s, like the reaction to the crime problem in the late 1960 s, did not center on young offenders for a number of years. Since about 1993, however, the young offender and particularly the violent young drug offender has been a special target of public anxiety and governmental activity.

One aspect of the attention young offenders are getting in the 1990s is brand new, rather than merely a cyclical recurrence. For the first time in modern history, middle-adolescent offenders are being identified as a high-risk and highusage group for firearms. The federal Office of Juvenile Justice and Delinquency Prevention now issues reports on reducing youth gun violence. ${ }^{2}$ Drive-by shootings, fear of guns, the demand for metal detectors in schools, proposals for special legislation, these are the youth violence soundbites of the 1990s. The most poignant reminder of the change in public focus was the passage of a federal law that established the creation of "gun-free schools" as a policy ambition of the national government. ${ }^{3}$ The sad part of this stated ambition is that gun-free schools were regarded as an accomplished fact for all of previously recorded American history.

This essay is a brief examination of three dimensions of the juvenile firearms use epidemic of the period since 1985. Part II of the essay will examine the factual foundation for concerns about rising youth gun use. It will compare

\footnotetext{
Copyright $\odot 1996$ by Law and Contemporary Problems

* Professor of Law and Director, Earl Warren Legal Institute, University of California-Berkeley.

I thank Phil Cook and Lee Robins for helpful reactions to an earlier draft.

1. See, e.g., CONFRONTING YOUTH CRIME: RePORT OF THE TWENTIETH CENTURY Fund TASK FORCE ON SENTENCING POLICY TOWARD YOUNG OFFENDERS (1978) (background paper by Franklin E. Zimring).

2. Office of Juvenile Justice and Delinquency PRevention, Reducing Youth Gun VIOLENCE (1995).

3. Gun Free Schools Act of 1994, 20 U.S.C. $\S 8921$ (West 1996).
} 
recent trends with prior patterns and discuss some of the ways that current conditions are without precedent for students of firearms violence and of youth crime. Part III will consider some of the data that is required to make intelligent choices when designing countermeasures to the misuse of guns by minors. Because most of the necessary data is currently unavailable, the second half of Part III will present a series of best guesses about the peculiar circumstances of guns and adolescents in the 1990s. Part IV will show that the same qualities of irresponsibility that justify laws that prohibit minors from acquiring weapons that are freely available to adults should also limit the amount of punishment that can be administered to those young offenders who violate the prohibition.

\section{II}

\section{THE EPIDEMIC OBSERVED}

The factual foundation for concern about firearms and youth violence comes from police and health statistics on homicides involving youth. Figure 1 is one of several versions in circulation of the data showing the trends in gun and nongun homicides involving offenders under age eighteen. Homicide arrests reported by the Federal Bureau of Investigation ("FBI") are the basis for the annual statistics in the figure.

FIGURE 1

NUMBER OF GUN AND NONGUN HOMICIDES

BY JUVENILE OFFENDERS (age 10-17), 1976-1992

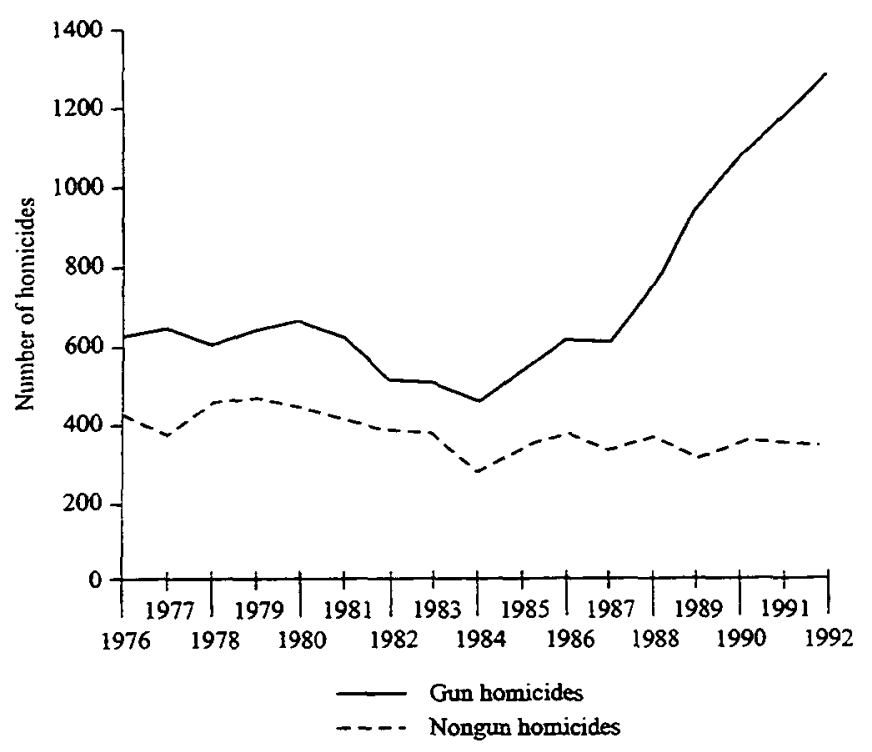

Source: FEDERAL BUREAU OF INVESTIGATION, U.S. DEP'T OF JUSTICE, UNIFORM CRIME REPORTS: SUPPLEMENTARY HOMICIDE REPORTS 1976-1992 (1st ICPSR version, 1994) (CD-ROM). 
The volume of homicide arrests in the age groups ten to seventeen more than doubled between 1984 the low point in the time series-and 1992, from 960 to 2,360 , and the volume of homicide arrests in 1992 was nearly double any pre-1988 year. However, growth in arrests was very unevenly distributed between gun and nongun killing cases. Nongun killing arrests increased only twenty-four percent from the 1984 low point to 1992. Additionally, the 466 arrests in 1992 for homicides by all means other than gun is the fourth lowest total recorded during the seventeen years from 1976 to 1992.

Almost all of the increase in arrests came in gun cases, where arrests increased 229 percent in eight years. The 1,850 arrests for ages ten to seventeen for homicides involving guns were more than double the volume recorded in any year before 1988. If homicide arrests are an accurate measure, killings by young offenders more than doubled since 1984 and the trebling of gun cases was the only significant cause of the general increase.

There is some question, however, about whether homicide arrests are a good measure of youth homicide trends. For one thing, arrest data only exist when a killing produces arrests, so the data in Figure 1 undercounts youth participation in homicide. Killings involving young offenders will not be counted if no arrest results. Also, because the same fraction of cases may not result in arrests in any two years, trends in arrests over time may not reflect trends in killing over time. The FBI reports that the percentage of cases solved to the satisfaction of the police for homicide were seventy-four percent in 1984 and sixty-five percent in 1992, so the trend in arrests might understate the increase in youth homicide by twelve percent on account of declines in clearance rates. ${ }^{4}$ There is no reason to suppose that clearance rates differ greatly for gun and nongun cases.

Another reason why arrest trends may distort homicide trends is that many cases, particularly crimes involving teenagers, produce multiple arrests in the same case. ${ }^{5}$ Figure 2 is drawn from the same database as Figure 1, the FBI's Supplementary Homicide Reports, but the volume of cases reported are the number of victims killed by offenders aged ten to seventeen from 1976 to 1992. The data will end any multiple counting because of multiple arrests, but they do not account for any uncleared cases that might have involved young offenders.

4. See federal Bureau of InVestigation, Crime in the United States 154 (1984); FEDERAL BUREAU OF INVESTIGATION, CRIME IN THE UNITED STATES 208 (1992).

5. See generally Franklin E. Zimring, Kids, Groups, and Crime: Some Implications of a WellKnown Secret, 72 J. CRIM. L. \& CRIMINOLOGY 867 (1981); Albert Reiss, Co-offending Influences on Criminal Careers, in CRIMINAL CAREERS AND "CAREER CRIMINALs" 121 (Alfred Blumstein et al. eds, 1986). 
FIGURE 2

NUMBER OF GUN, NONGUN, AND TOTAL HOMICIDES

BY JUVENILE OFFENDERS (age 10-17), 1976-1992

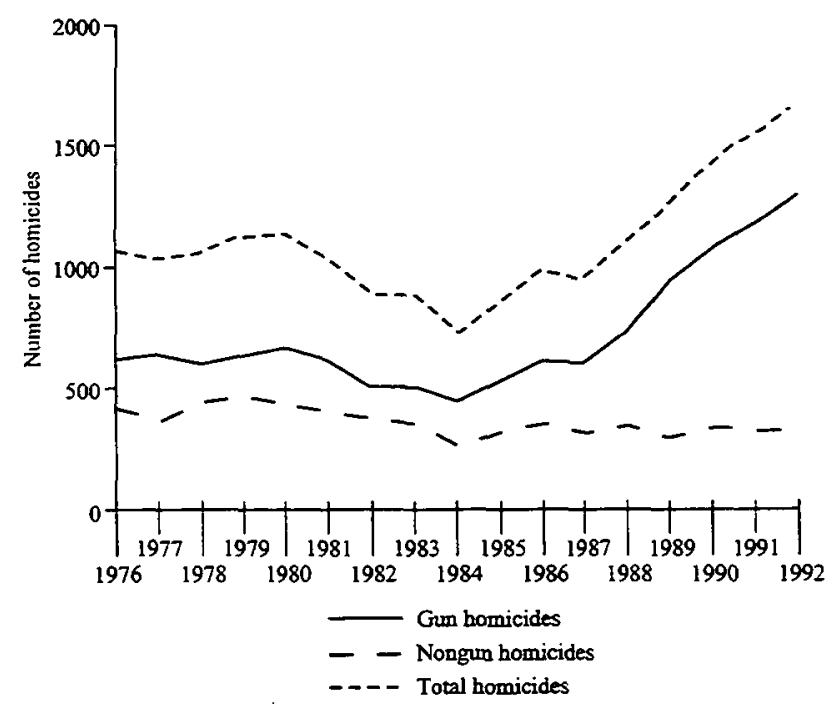

Source: Federal Bureau of InVESTIGATION, U.S. DEP'T OF JuSTICE, SUPPLEMENTAL Homicide REPORTS 1976-1992 (1st ICPSR version, 1994) (CD-ROM).

The number of killings is much smaller for this age group than the number of young persons arrested. In 1992, the 2,364 young persons arrested were involved in a total of 1,663 cases or about sixty percent of the arrest total. The ratio of arrests to crimes had increased from 1984 to 1992 for gun cases from 1.25 to 1.43. Therefore, some of the steep increase in gun cases noted in Figure 1 was an artifact of increasing arrests per killing on gun cases, while arrest-tocrime ratios remained unchanged at 1.4 to 1 for nongun cases. Slightly more than one-fourth the increase in gun cases from 1985 to 1992 disappears when each killing is counted only once in Figure $2 .^{6}$

With these corrections made, however, the basic message of Figure 2 remains quite close to that conveyed by Figure 1 . The number of homicides involving kids has doubled in eight years. Virtually all of the increase is the result of a 160 percent increase in gun killings where one suspect is between the ages of ten and seventeen.

The patterns reported in Figures 1 and 2 have three remarkable elements: (1) the gun cases determine almost all of the increase and decrease in the total homicide rate; (2) the reversal over time of the extent to which young offenders

6. The growth rate in gun case arrests, 449 to 1,850 , is $229 \%$ compared to a $160 \%$ growth in gun killings involving the same ages. 
use guns in homicide; and (3) the magnitude of the age-specific increase in gunrelated homicide.

First, almost all of the variance-up and down-is in the gun component of youth homicide from 1976 to 1992 . What sets this sixteen-year record apart from other time-series accounts of homicide by weapon is not the tendency of gun killings to disproportionately increase in up years and decrease in down years; this is a general tendency that has been noted before. ${ }^{7}$ What is different about Figure 2 is the prettiness of the picture. If 1984 is the base year, gun cases account for sixty-one percent of all homicides in that year, but over ninety-one percent of the additional homicides observed between 1984 and 1992. It very much looks as if the total homicide volume attributable to the age group ten to seventeen doubles in less than a decade and gun use is the only visible cause. Over the seventeen-year period, the correlation between the percentage of all juvenile homicides committed with guns and the total homicide rate is 0.9 , indicating that fluctuations in the proportion of youth homicide committed with guns might explain eighty percent of the variation in total homicide rates.

The apparently single cause dynamic is of importance for both youth policy and for scientific investigation of the determinants of death rates from assault. From a policy standpoint, the data in Figure 2 make the identification of policy goals in youth violence what is called a "no brainer." It would be difficult to create a set of weapon-specific homicide trends that would underscore the importance of guns more than Figure 2, and while it may be possible to explain the pattern shown in the figure without putting major responsibility on increased gun use, I would not be happy to be assigned that side in a debate.

The pattern set out in Figure 2 also has a less obvious implication. It presents new evidence that variations in gun use can have a powerful influence on the death rate from attacks. The assault rate among adolescent males is chronically high and has been so since long before victim surveys were first conducted. Yet the death rate from youth assault was and is very low. Figure 2 shows that changes in gun use that might affect only a very small share of total youth assaults can carry major impact on death rates. The high correlation between percentage gun and total death rates attributable to this group is new evidence that gun use influences the death rate from assault.

That gun use has a dramatic impact on homicide rates is not strict proof that the instrument used in assaults has a large impact on death rates independent of the attacker's intentions. Increases in gun use will usually involve both an increased willingness to use maximum force when conflicts occur and the increased lethality of the gun as an instrument of attack. The data from Figures 1 and 2 show that the joint effects of changes in weapon dangerousness and the willingness to use these weapons has a significant impact on homicide rates.

7. See generally Franklin E. Zimring, Firearms and Federal Law: The Gun Control Act of 1968 , 4 J. LEGAL STUD. 133 (1975). 
Detailed studies at the individual event level are necessary to address the influences of instrument and intention separately. ${ }^{8}$

A second interesting aspect of the changes documented in Figure 2 is the change in the relative propensity of different age groups to use guns in homicide. Table 1 shows the proportion of gun use in homicide cases involving juveniles and young adults for 1978 and 1992.

TABLE 1

PeRcent Gun Use in Homicide By AgE of OfFENdeR

Juveniles (10-17)

Young Adults (20-29)

All other ages

$\begin{array}{cc}\frac{1978}{57} & \frac{1992}{78} \\ 62 & 67 \\ 64 & 69\end{array}$

In 1978, homicides with offenders aged ten to seventeen involved guns in fifty-seven percent of all cases, significantly below the gun cases involving all other age groups, where sixty-four percent of all cases were gun homicides. By 1992, this ten-to-seventeen gun share had increased to seventy-eight percent or nine percent above the gun share for all other age groups. The lower 1978 gun share for juveniles is not difficult to explain. Children under eighteen are prohibited from buying firearms by federal law, along with felons and other special groups. ${ }^{9}$ So the legal framework facing minors is much more restrictive than that facing adults. Studies of youth crime in the 1970s showed that robbery by young teenagers in New York City had a much lower death rate than robbery by older offenders, presumably because of lower rates of gun use in robbery. ${ }^{10}$

By 1992, however, juveniles committing homicide used guns more often than any other age groups. What happened?

Others have speculated about the social processes that may have increased juvenile gun use in the late $1980 \mathrm{~s}^{11}$ My ambitions here are restricted to discussing what underlying changes in youth gun ownership and behavior the gun trends in Figure 2 imply. The uptrend in gun killings is strong evidence that the number of gun assaults by juvenile offenders increased substantially since 1984. But that does not necessarily mean that the proportion of attacks committed by young offenders with guns is greater than the average for older groups. The overwhelming majority of all assaults by minors involve the use of

8. See, e.g., Frank Zimring, Is Gun Control Likely to Reduce Violent Killings?, 35 U. CHICAGO L. REV. 721 (1968).

9. See Zimring, supra note 7, at 151-52 (citing Gun Control Act of 1968, 18 U.S.C. § 922 (d)(3)).

10. Franklin E. Zimring, Youth Homicide in New York: A Preliminary Analysis, 13 J. LEGAL STUD. 81 (1984).

11. See, e.g., Alfred Blumstein, Youth Violence, Guns, and the Illicit-Drug Industry, 86 J. CRIM. L. \& CRIMINOLOGY 10 (1995). 
personal force on other teens, attacks that almost never kill. It is possible that the gun share in serious youth assault could remain under ten percent even as the proportion of killings involving guns approaches eighty percent.

Even when the proportion of gun killings committed by young killers exceeds the proportionate gun use in adult homicide, this does not mean that gun ownership by kids is higher than or equal to adult ownership rates. There are fewer than 2,000 juvenile gun killings each year and many millions of juveniles. Teen handgun ownership could be much lower than adult handgun ownership as long as the average handgun under the control of a juvenile is much more likely to be used in an assault than the average handgun owned by an adult, not an unlikely prospect. What we know is that a larger number of guns than earlier are under the control of kids by the early 1990s. What we do not know is the size of the juvenile gun inventory. And the margin of error on this question is probably quite large.

The third novel feature of the period since 1984 is the magnitude of the upsurge in gun use for the younger age group. It has always been assumed that gun availability was a general phenomenon in an area that affected all groups in a more or less equal fashion. When gun density increased, it was thought that a rising tide carried all boats and decreases in gun availability were also supposed to have general effects. But the rising tide since 1984 has not carried all major age categories in anything resembling equal fashion. From 1984 to 1992, the percentage of all homicides involving guns moved from sixty to sixtynine percent, an increase on the base of fifteen percent in eight years. During that same period, the percent gun use in juvenile homicide increased from fiftynine percent to seventy-eight percent, an increase from the base of thirty-two percent.

This age-specific pattern is a challenge to researchers to find out whether patterns of ownership and control were changing more in one age group than in others or whether the same gun availability shifts had different impacts on youth violence. It would be incorrect to say that the jury is still out on this question; a jury has not yet been impaneled. But the issue deserves careful investigation now that recent history has called it to our attention.

The age-specific difference in gun share is also a bit of a natural experiment on gun use and the death rate from violence. Gun share moved from sixty to sixty-nine percent for nonjuveniles from 1984 to 1992, and the homicide rate for this group increased by fifteen percent. The gun share for juveniles increased from fifty-nine to seventy-eight percent, and the death rate increase was 128 percent. Res ipsa loquitur.

Figure 3 provides age-specific detail on the growth of gun use in homicide in 1984 and 1992 for ages ten to twenty. Homicide arrests are used here to give every arrested person a single age entry in the analysis. 
FIGURE 3

Percentage of Homicide CommitTed by Gun and Homicide RATE BY OFFENDER'S AGE, 1984 and 1992

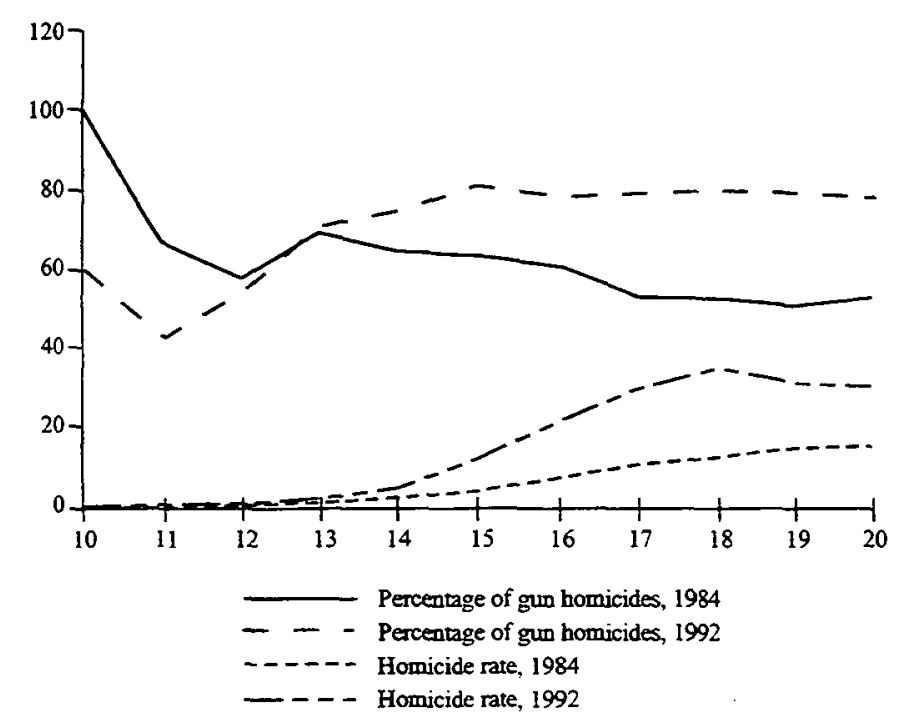

Source: Federal BUREAU of INVESTIGATION, U.S. DEP'T OF JUSTICE, SUPPLEMENTAL HoMiCIDE REPORTS 1976-1992 (1st ICPSR version, 1994) (CD-ROM).

The 1984 homicides show a relatively flat distribution by age with the percentage gun use as high among fourteen- and fifteen-year-old offenders as among offenders ages sixteen, seventeen, and eighteen. The 1992 cases show increases at every age past thirteen in gun share but larger increases in the later years. This difference in pattern allows one further test of gun share as a predictor of change in homicide rate. The two pattern lines in Figure 3 compare the rates per 100,000 in homicide for each age group for 1984 and 1992. The hypothesis being tested is that those age groups with the largest increase in percentage of homicides committed with guns will also have the largest growth in total homicide rate per 100,000. A visual inspection of Figure 3 supports this interpretation. This is confirmed by a .84 correlation between change in percentage gun use from 1984 to 1992 and the change in homicide rate experienced by an age group.

\section{III}

\section{A Prologue to Control Strategies}

How much do we know about how to design strategies to reduce handgun possession, handgun carrying, and handgun use by teenagers? When knowledge gaps exist, what are plausible guesses about promising ways to reduce gun availability and use? The previous section argues that sharp increases in the share of youth homicide attributable to guns almost certainly tells us that gun 
ownership in this youngest age group was expanding. However, gun ownership might not have been expanding as much in the youth population as a parallel increase in homicide gun share for an older group would usually signal. One way to test the breadth of the expansion of gun ownership among crime-prone youth would be to study the equivalent shift in the percentage of under-eighteen offenders arrested for robbery and assault who use guns. Although data on weapon use by age of arrests for robbery and assault are not available in the aggregate FBI's Uniform Crime Report statistics, city-level data should be identified and studied.

To facilitate the design of youth gun strategies, better and more detailed information is needed on the extent of youth gun ownership and use, and on patterns of acquisition of guns by minors in various gun inventory environments. We also need post-retailer traces of guns taken from young offenders to see how guns travel from first dealer sales to adolescent users and how long after a weapon comes under the control of a minor the firearm comes to the attention of officials. The existing federal Bureau of Alcohol, Tobacco, and Firearms ("BATF") resources can be tied to criminal enforcement traces of guns after retail purchase. ${ }^{12}$ Tracing weapons in this way is an important way of testing the unverifiable accounts that young persons give in surveys. The BATF can generate this data if youth gun markets become a high agency priority.

Designing countermeasures on current information to remove guns from juvenile control is a guessing game with an uncomfortably ample margin of error. With this warning, let me list a few personal guesses about the conditions of handgun availability and use among young persons in 1996 and the types of tactics that these conditions suggest might prove fruitful. A concluding section raises a jurisprudential limit on youth gun enforcement that should restrict the use of punishment in this process even if that hampers the effectiveness of the program.

The first set of guesses I would make about fifteen-, sixteen-, and seventeenyear-old potential gun holders is that their behavior is different from older, potential gun owners. One difference concerns the distinct political economy of adolescents. Kids that age tend to have shorter monetary attention spans than adults, less monetary capital, and less regard for pieces of property as capital assets over a long term. Economic wants are many and the adolescent consumer can easily be distracted from one desired acquisition by the presence of alternative desired goods. Philip Cook and his associates reported rapid turnover of guns and a willingness to trade guns for money or other consumption items like drugs, CD players, and auto equipment. ${ }^{13}$

It would not be surprising to find these motives and behaviors even among teenagers at high risk of using guns. Under these circumstances, raising the

12. Bureau of alcohol, Tobacco, and Firearms, Operation Identification (1976); Franklin E. Zimring, Street Crime and New Guns: Some Implications for Firearms Control, 4 J. CRIM. JUST. 95 (1976).

13. Philip J. Cook et al., Regulating Gun Markets, 86 J. Crim. L. \& CRIMinology 59, 65 (1995). 
price of a gun has two positive effects. It can make those who do not own guns less likely to buy them and those who do possess guns more likely to sell them. The second impact could be greater than the first. Undercover purchases combined with efforts to constrain the supply channels used by kids seems particularly promising.

Efforts at creating ammunition scarcity for those who possess guns may also hold more promise for younger juveniles than for adults. The relatively free availability of ammunition to adults means there is not much of a black market in bullets. But kids need to use straw purchasers to obtain ammunition from legitimate channels. In some circumstances, efforts to make handgun ammunition difficult to obtain may be much more effective for a youth market than for adults, even adults not legally qualified to purchase ammunition, because adults can lie about their status while younger adolescents are often visible in their youthful disability.

It is not known how elastic the demand for guns and ammunition is among younger adolescents at particularly high risk of misusing guns. The higher their elasticity, the greater the prospects that control initiatives can produce visible impact. One major task of policy experiments is to answer this question.

One final guess about enforcement conditions is important to my priorities for testing countermeasures to adolescent gun use. Jurisdictions with low general rates of ownership and tight legal controls on handguns and ammunition for adults may be more attractive settings for special efforts to deny guns to kids than jurisdictions with high levels of handgun availability to the general population. The reason for this is that a smaller number of guns are in general circulation in such settings. There are usually many more potential sources of handguns in a loose control environment. Cut off one channel of supply and another can be easily found, including guns at home or available for theft in other homes. Replacements for interrupted channels of supply might not be that easy in a tight handgun control jurisdiction with a relatively small inventory of guns in households, for example, New York City or Newark, New Jersey.

The only data available on gun use by youths concern homicide, which do not directly address whether there is a different environment for control in low inventory cities. Gun share for offenders ten to seventeen went from nineteen percent in New York City to eighty percent between 1984 and 1992. ${ }^{14}$ In Houston, the increase was from sixty-five to eighty-nine percent. Obviously the two cities differed in the base year. But the two cities are also probably much different in 1996, with many more guns in Houston. A relatively small number of guns could have produced the huge increases in the percentage gun use in New York City youth homicide.

The different conditions that interact with efforts to make guns unavailable to minors may or may not call for different tactics in high gun inventory and

14. Federal Bureau of Investigation, U.S. DeP'T of Justice, Supplemental Homicide REPORTS 1976-1992 (1ST ICPSR VERSION, 1994) (CD-ROM). 
low gun inventory environments. But the better prospects for success in low inventory conditions do argue for a major share of the public resources that will be devoted to youth gun initiatives going to low availability sites.

Using kids as paid information sources and creating large rewards for successful identification and interruption of suppliers are additional ways in which financial incentives can be used in youth gun programs in low inventory environments. These same tactics might also succeed in areas with more guns and more methods of resupply. But the best case test of a new approach would be in a low handgun inventory environment.

Both market research and the creative use of financial incentives may have special promise in working with middle-adolescent, high-risk handgun ownership. Much may be accomplished in the design of site-specific countermeasures by talking to kids about their motives for gun possession and conditions in which they might give them up. In the cases where gang conflict is a real motivating force, bilateral buy-back agreements and nonuse treaties with financial compliance incentives are possibilities.

IV

\section{IMMATURITY AS JUSTIFICATION AND CONSTRAINT}

In the jurisprudential shorthand of the juvenile court, the prohibition of handguns to minors when adults are allowed such weapons can be described as a "status offense" because the behavior of the young person who violates this law is an offense only because the minor is not a legal adult. In this sense, the provisions of federal and state gun control laws are parallel to laws forbidding the young access to alcohol, cigarettes, the operation of motor vehicles, and gambling games available to adults. Other status offense regulations include curfews applied only to young persons and compulsory school attendance laws that can produce truancy charges.

Despite the definitional similarity of all age-related prohibitions, status offense prohibitions to youth fall into two discrete categories of justification: those designed only to protect the young person and those designed to protect the community as well as the youth from harm. The prohibitions on smoking, truancy, and gambling are clear examples of restrictions aimed at the protection of young persons exclusively. The age restrictions on motor vehicle operation and guns seem clear examples of prohibitions intended to protect the community from the dangers of immature drivers and shooters. Restrictions such as alcohol bans and curfews probably also serve some explicitly community protective purposes. ${ }^{15}$

Even when community protection is the goal of an age-related prohibition, the justification for imposing the prohibition on the young may still limit the extent to which young persons who violate the law deserve punishment. Why

15. Franklin E. Zimring, The Changing legal World of Adolescence 68 (1982). 
should we worry about minors having guns, particularly in environments where adults can freely possess large numbers of weapons? The special problem of youth is immaturity. The rationale for age-specific prohibition of gun acquisition and use is that fifteen- and sixteen-year-olds are not believed to be sufficiently mature to be trusted with deadly weapons, even when free availability is the adult standard. Immaturity justifies restriction of firearms access both because kids need to be protected from the consequences of their own bad judgments and because other people need to be protected from armed and dangerous teens. So the very deficiencies of judgment that lead to violations of the law are expected by the law; indeed, they justify the special restrictions that led to the violation.

This does not mean that minors should be immune from punishment for obtaining guns. But it does place an upper limit on the level of punishments that can properly be imposed on a young offender. And it also means that adults who are guilty of knowingly assisting the forbidden use of guns by minors should be regarded as more culpable than the targets of their assistance. The adults should know better.

Suppose the legislature finds that there is special danger in fourteen-yearolds possessing loaded handguns. Does that justify passing a law that treats any fourteen-year-old possessing a handgun as an adult in criminal court and imposing a mandatory ten-year prison term on conviction of the offense? ${ }^{16}$ The jurisprudential problem with such a law is that it depends on two inconsistent versions of the moral and intellectual abilities of the fourteen-yearold. On the one hand, the legislature sees minors as possessing poor judgment and weak impulse controls. On the other hand, it seeks to treat a teenager who by violating the law has proved the legislative characterization correct as if he were now regarded as fully mature and responsible. If the young offenders were all that mature, their possession of the firearm should not be a special offense. When the juvenile targets of special age-related prohibitions turn out to be as immature as we feared, their diminished capacity should limit the extent of their penal liability. ${ }^{17}$

In this respect, the teenage gun violator is distinguishable from the convicted felon, the other major class of person prohibited from acquiring guns by the federal Gun Control Act and state licensing laws. The reason the felon is restricted from ownership is not immaturity, but because his previous voluntary wrongful conduct has placed him in a class with higher danger when possessing guns. Full penal responsibility can attach to gun law violations of this kind without any jurisprudential inconsistency.

16. When this example was framed for a draft presented at the conference, it was hypothetical. Since then, in another case of life imitating art, Mike Reynolds of "three strikes and you're out" fame in California has proposed a mandatory minimum ten-year term for gun offenders as young as fourteen. Pamela J. Podger, FRESNO BEE, Oct. 18, 1995, at A1.

17. See ZIMRING, supra note 1 , at $80-88$. 
Similarly, the adult who sells to a teen is by the logic of the age-specific ownership prohibition more culpable than the teen who buys from the adult. This suggests a priority in law enforcement that places special emphasis on the identification and prosecution of culpable adults. But consistent legal policies must reduce the maximum punishment of the underage offenders in recognition of the same tendency toward age-based immaturity and impulsiveness that justify weapons prohibitions for minors.

The significance of immaturity on the sentencing of young gun offenders is one example of a broader point. It is vital to return to the basic justifications for various types of restrictions on gun ownership to make sure that the tactics we employ in regulating firearms do not contradict the basic purposes of the regulations. One of the great dangers in framing gun control policies toward young persons without reference to basic principles is that those who enforce the law may do so in ways that inadvertently do a disservice to the values and objectives that led to the law's enactment.

\section{$\mathrm{V}$ \\ CONCLUSION}

While homicides involving other weapons have not increased, youth homicide cases where guns were the lethal weapon have increased dramatically. The elevated dangers of kids with guns justifies a special policy focus on reducing handgun ownership and use by juveniles. However, the lack of mature judgment that argues for prohibiting kids from owning guns also limits the degree to which the same kids can be punished for disobeying the law's command. Appropriate policy on this important issue requires careful attention to basic principles. 
HeinOnline -- 59 Law \& Contemp. Probs. 381996 